\title{
Empoderando nossos Úteros: por uma prática de afirmação da vida
}

Empowering our wombs: for a life-affirming practice

\author{
Patricia de Lima Caetano \\ Universidade Federal do Ceará
}

DOI: 10.12957/mnemosine.2020.57653

Útero. Cavidade primeira de todos os começos... $O$ fértil pântano original em que a vida pode se desenvolver:

(O primeiro) ninho, segurança;

Órgão a partir do qual se expressa o ritmo (feminino);

Músculo extremamente forte. ... Alojar a vida, alimentar, abrir-se e conceder a vida (pelo nascimento). (Significado simbólico para útero, por Rüdiger Dahlke)

No dia 31 de outubro de 2019, em uma sala da Universidade do Estado do Rio de Janeiro (UERJ), dez mulheres se encontraram para, juntas, fazerem contato com seus úteros-ovários e dançá-los. Dez mulheres dançaram seus úteros-ovários, juntas. Muito provavelmente, elas não sabiam o que iria acontecer neste encontro, mas de algum modo se sentiram contagiadas e convocadas a empoderarem coletivamente seus, nossos úteros. Juntas. E eu fui uma dessas mulheres.

Compondo com a programação do evento "Políticas e poéticas de contágio: ensaios de viver entre muitxs", Empoderando Nossos Úteros consistiu em uma proposição prática. Por meio dela, propus encontrarmo-nos sensivelmente com este ambiente-território do corpo - o ventre e suas populações: a cintura pélvica, sua dimensão óssea; o útero, sua dimensão orgânica; e os ovários, sua dimensão glandular. Entre imagens, toques, cheiros, ressonâncias sonoras, movimentos, olhares e trocas vibráteis, procuramos reconhecer um ambiente-território do corpo, entre tantos ambientes-territórios do corpo (ah... essa multiplicidade, a corporeidade), e nele habitar. 
Em reconhecendo-o, habitar.

Em habitando, transformá-lo em um lugar para ser-estar.

Habitar, habitat. Nos habitar. Habitat-nos.

Ventre-habitat.

Como em um ecossistema, naquela tarde do dia 31 de outubro, dez mulheres juntas adentraram um ambiente repleto de coletividades celulares vibráteis co-existindo em interdependência e interconectividade ${ }^{1}$. Sim, os ambientes-territórios do corpo, como todo e qualquer ambiente de um ecossistema vivo, são também eles ambientes cooperativos. Sim, a corporeidade é composta por existências cooperativas. Conglomerados celulares em interdependência e interconectividade: a existência óssea cooperando com as demais existências orgânicas e glandulares... Somos uma rede viva! Nossas células em comunicações ressonantes bem sabem disso!

Permanecer nele - o ventre e suas populações - por mais tempo, com atenção sensível: entre olhos de ver, olhos de ouvir, olhos de cheirar e sentir, olhos de lembrar. Respirar nele. Respirar com ele. Respirar através dele. Ir reconhecendo suas formas, seus volumes, suas vibratilidades, suas densidades e rarefações, seus cantinhos, suas dobras, sua maciez e suas firmezas, suas estruturas, seus vetores, suas sinuosidades, suas forças, suas conexões, suas imagens-sensações...

Com os olhos de cheirar,

Receber um aroma de flor,

Acariciar a pele-ventre,

Conectar a pele-útero,

Acolher

Contorno primeiro.

Com os olhos de tocar,

Olhos da pele-mão

Sentir, tatear,

Abrir o território..

Pele porosa, 
Ponte para uma útero-presença.

Com os olhos de tocar

Ovários-conchas energéticas,

Expandir seus fios invisíveis..

Olhos nas pontas dos dedos,

Sutilmente,

Pulsam sua potência invisível,

Entre,

Espaços múltiplos..

Com os olhos de ver,

Reconhecer ossos

Asas ilíacas,

Púbis, sacro, cóccix.

Ver mapa de um abrigo seguro,

Reconhecer cavidade-terra-firme.

Com os olhos de ver,

Reconhecer órgãos-glândulas

Útero flor

Trompas, ovários.

Ver mapa de um abrigo visceral,

Reconhecer caverna-primordial.

Com os olhos de sentir

Mover terra-firme,

Rolar ossos-ísquios,

Debruçar bacia,

Derramar líquidos esquecidos..

Deixar brotar rio à frente, rio atrás,

Permitir-se fluir.. 
Rio à frente, rio atrás, rio acima, rio abaixo,

Rio adentro, rio afora.. rio.

Com os olhos de sentir

Mover abóboda-pélvica,

Ser movida..

Transbordar volume orgânico,

Ser dançada..

Dançar ritmo visceral,

Reverberar gestos-pulso..

Com os olhos de sentir

Fincar calcaneos na terra firme,

Projetar fios ovarianos,

Brotar para dentro da terra..

Terra fora

Terra dentro

Terra dentro-fora-dentro..

Fora-dentro.

Ser Pântano-raíz

Umidificar/regar a terra de si

Com os olhos de sentir

Cuidar da propria terra,

Afirmar um lugar,

Território ativo de acolhimento.

Uterizar....

Uterizar a vida

Uterovarizar.......

Uterovarizar o existirmo-nos. 
Ser receptivo é ser assertivo ${ }^{2}$ com a vida!

Ser assertivo com a vida, recepcionar ativamente para brotar dentro-fora..

Brotar mundos

Brotar dentro-fora, mundos.

Ativamente conceder o porvir..

Ao experienciar nossos úteros, vivenciamos suas imagens-sensações entre muitxs! Corporalizamos um espaço-território do(s) corpo(s) feminino(s). Afinal, são tantxs!......

Cuidar da vida consistiu em afirmar um espaço-território do acolhimento em si, entre muitxs de si e do outro. Chegar pisando de mansinho nesse espaço-território primordial para permitir abrirmo-nos a uma experiência de encontro com uma útero-potência.

No dia 31 de outubro de 2019, em uma sala, dez mulheres se encontraram para, juntas, empoderarem os seus úteros, como fariam talvez suas/nossas ancestrais, em uma prática de acolhimento de seus/nossos férteis pântanos originais. Uma afirmação da vida pela prática do cuidado entre muitxs.

...Dez mulheres, juntas, reconheceram e acolheram os seus úteros-ovários em suas mãos e dançaram seus úteros-fluxo, suas raizes, suas águas, suas forças, suas memórias de pertencimento a um útero-terra-mater...

\section{Referências}

COHEN, Bonnie Bainbridge. Sentir, Perceber e Agir: educação somática pelo Body-Mind Centering. São Paulo: Edições Sesc São Paulo, 2015.

DAHLKE, Rüdiger. A doença como símbolo. Pequena Enciclopédia de Psicossomática. SP: Editora Cultrix. 1996.

HERRERO, Amaranta. Conexiones entre la crisis ecológica y la crisis de los cuidados. Entrevista a Yayo Herrero López. Espanha, 2018. EcologíaPolítica. \#54 Ecofeminismos. Disponível em: http://www.ecologiapolitica.info/?p=10256 . Acesso em: 30 de junho de 2018.

Patricia de Lima Caetano Universidade Federal do Ceará E-mail: tita.caettana@gmail.com 


\footnotetext{
${ }^{1}$ Em um sentido relacional da vida, Herrero nos fala sobre ecodependência e interdependência: "Y cuando empecé a ver cómo los análisis feministas planteaban la radical vulnerabilidad de cada vida humana en solitario y que no solamente somos seres ecodependientes, sino también interdependientes, me di cuenta de que, en efecto, los problemas de sostenibilidad de la vida humana no se pueden abordar pensando solo en las relaciones con la naturaleza, sino que también hay que pensar en las propias relaciones entre las personas. Me pareció que la mirada ecofeminista, al poner en diálogo ambas miradas, me permitía comprenderme mucho mejor como especie y como persona, así como comprender mucho mejor el sentido relacional de la vida en su conjunto." (HERRERO, 2018)

${ }^{2}$ A partir de percepções compartilhadas por pessoas em seus cursos de Body Mind Centering ${ }^{\mathrm{TM}}$, Bonnie B. Cohen, a criadora desta prática somática, nos lança pistas emocionais para o órgão Útero: "assertividade profunda e acomodação". Já para o órgão Vagina: "assertividade superficial e acomodação" (2015: 87). Baseei-me na prática somática do Body Mind Centering ${ }^{\mathrm{TM}} \mathrm{e}$ nas minhas próprias descobertas pessoais para a realização da proposição prática Empoderando Nossos Úteros.
} 